УДК 821.111 .09

Білоконенко I. C., кандидат філологічних наук, старший викладач кафедри російської філології та зарубіжної літератури Криворізький державний педагогічний університет

\title{
ТВОРЧІСТЬ МЕРІ СІДНІ ГЕРБЕРТ У КОНТЕКСТІ СЛИЗАВЕТИНСЬКО-ЯКОБІНСЬКОГО ПЕРІОДУ ІСТОРІЇ АНГЛІЙСЬКОЇ ЛІТЕРАТУРИ
}

Стаття присвячена аналізу творчого надбання Мері Сідні Герберт, графині Пембрук у контексті єлизаветинсько-якобінського періоду історії англійської літератури. Звернуто увагу на діяльність ї літературного салону «Академія»; редагування й публікацію літературної спадщини брата Ф. Сідні; переклади творів Ф. Дюплессі-Морне, Р. Гарньє, Петрарки; біблійних псалмів. Проаналізовано особливості авторського стилю поетеси.

Ключові слова: Мері Сідні Герберт, єлизаветинсько-якобінський період історії англійської літератури, Філіп Сідні, «Академія», Шекспір, Петрарка.

Статья посвящена анализу творческого наследия Мэри Сидни Герберт, графини Пембрук в контексте елизаветинско-якобинского периода истории английской литературы. 
Обращено внимание на деятельность ее литературного салона "Академия»; редактирование и публикаиию литературного наследия брата Ф. Сидни; переводы произведений Ф. Дюплесси-Морне, Р. Гарнье, Петрарки; библейских псалмов. Проанализированы особенности авторского стиля поэтессы.

Ключевые слова: Мэри Сидни Герберт, елизаветинско-якобинский период истории английской литературы, Филипп Сидни, «Академия», Шекспир, Петрарка.

The article analyzes the creative heritage of Mary Sidney Herbert, Countess of Pembroke in the context of the Elizabethan-Jacobin period of English literature. Attention is paid to her role at the literary salon "Academy»; her contribution as editor and publisher of F. Sidney's literary heritage; her activity as translator of Biblical psalms and works written by F. Duplessis-Mornay, $R$. Garnier, and Petrarch. The features of the author's writing style were analyzed.

Keywords: Mary Sidney Herbert, Elizabethan-Jacobin period of the English literature, Philip Sidney, «Academy», Shakespeare, Petrarch.

Ім’я однієї 3 найвпливовіших аристократок єлизаветинської Англії, яка вважалася другою за освіченістю дамою після королеви, Делії, або Мері, Сідні (у шлюбі Герберт), графині Пембрук (Mary Herbert, Countess of Pembroke) відоме лише вузькому колу вітчизняних і зарубіжних дослідників. Вона була однією з найповажніших меценаток, поетес і перекладачок свого часу, з ії ім’ям пов’язана безліч таємниць і легенд. Уважається, що багато видатних постатей цього часу були зобов’язані своїм визнанням протекції й заступництву Мері Герберт [Young 1912; Fisken 1985; Hogrefe 1977]. А завдяки самовідданій любові до свого брата - одного з найяскравіших єлизаветинців Філіпа Сідні - i непересічному письменницькому таланту, наступні покоління читають сонети Ф. Сідні, тоді як мистецький здобуток графині Пембрук залишається чи то не впізнаним, чи то забутим. Навіть загальновідомі наукові джерела («Історія англійської літератури» [ІАЛ 1943], «Історія всесвітньої літератури» [ІВЛ 1985], «Історія зарубіжної літератури середніх віків та доби Відродження» [ІЗЛСВ 2007]) аж ніяк не згадують про Мері Герберт, або їхню увагу привертає лише іiі літературний салон «Академія» (як от в «Історії культури країн Західної Свропи в епоху Відродження» [ІКСЗС 1999:227]).

Різні аспекти вивчення постаті Мері Герберт пов’язані і з відповіддю на питання, чому iї творчість стала об’єктом для пошуків шекспірознавців. Вони десятиліттями не можуть дійти згоди щодо «провокаційної» ролі графині Пембрук у «шекспірівському питанні». С думка, що саме Мері та ії сини Уільям і Філіп - автори творів Шекспіра, а образ графині став основою для портрета 
У. Шекспіра [Новомирова 2003], або що вона була співавтором творів, написаних Р. Меннерсом і його дружиною, графинею Ретленд для письменника «Шекспіра» [Гилилов 2000:25-29]. Про декілька менш поширених антистретфордіанських гіпотез, у яких на роль автора шекспірівських творів теж пропонується Мері Герберт (i навіть сама королева Слизавета Тюдор) згадує Н. Торкут [Торкут 2005:17-18].

Отже, на сучасному етапі розвитку української літературознавчої науки видається актуальною спроба наукового аналізу творчого надбання Мері Герберт, графині Пембрук, яка була не лише талановитою поетесою, але й особою, причетною до багатьох суспільних i культурних процесів єлизаветинсько-якобінського періоду історії англійської літератури. Метою цієї наукової розвідки є реконструкція літературної репутації Мері Герберт, графині Пембрук, що враховує літературні здобутки відомої аристократки єлизаветинської і якобінської Англії.

Мері народилася в 1561 році в родині Генрі Сідні. Можливо, через те, що в ній текла славетна кров знатного англійського роду Дадлі, або те, що сімейство Сідні належало до категорії «нової знаті», Мері Сідні з раннього дитинства демонструвала нові погляди на життя. На цьому тлі варто згадати і їі успіхи в музиці, володіння декількома іноземними мовами, яскравий поетичний дар. Неординарність і краса юної дівчини не залишилися не поміченими - у віці чотирнадцяти років Мері Сідні стає фрейліною королеви Слизавети I.

Важливою подією в житті Мері був шлюб із Генрі Гербертом, 2-им графом Пембруком, тож у п’ятнадцять років вона переїжджає до маєтку Уілтон. Саме завдяки Мері Герберт маєток Уілтон набуває статусу літературного центру Англії, який сучасники називають «маленьким університетом». У різний час гостями літературного салону були найвидатніші особистості того часу: Ф. Гревілл - поет і співавтор «Літопису історії Англії та Ірландії за часів правління Єлизавети»; Е. Дайєр, М. Дрейтон, А. Фроунс - поети-лірики; Ф. Сідні, Е. Спенсер, С. Деніел - придворні поети Слизавети I; Н. Бретон поет-памфлетист та ін. 
До к. XVI ст. усі відомі митці були так чи інакше пов'язані із графинею Пембрук i iii літературним гуртком. Тут обговорювалися нові твори, влаштовувалися літературні турніри; точилися гарячі дискусії щодо потреби прославляти велич Англії та iї королеви, приклади мудрого правління; про благородних джентльменів, які мають возвеличувати націю; призначення поета в суспільстві і в літературному житті країни; стан англійської мови, яка не повинна поступатися грецькій і латинській; появу й розвиток в літературі нових жанрових форм, що до того не мали аналогів і зразків, хоч і формувалися 3 готових книжкових ситуацій (збірка еклог у формі календаря Е. Спенсера, цикл сонетів Ф. Сідні та Е. Спенсера, гуманістичний «високий» роман Ф. Сідні, національна героїчна епопея $\mathrm{E}$. Спенсера, пасторальна маска Дж. Лілі та Ф. Сідні, любовна лірика Ф. Гревілла, Е. Дайєра, С. Деніела, М. Дрейтона). Ф. Сідні в маєтку Уілтон планує й частково пише два романні варіанти на тему пасторальної Аркадії («Стара» й «Нова Аркадія»), обмірковує популярне на той час питання щодо проблем поетичного мистецтва - результатом цих роздумів стає трактат «Захист поезії». Складно заперечувати той факт, що саме з сестрою Філіп ділиться своїми думками, а вона підтримує брата в тих ідеях, які дають поштовх до розвитку англійської поезії, підносять ії до рівня італійської і французької. Усе ці події роблять літературний салон графині Пембрук місцем, що визначає тогочасні модні тенденції в англійській літературі.

Після смерті Ф. Сідні в 1586 році важливим завданням для Мері Герберт стає збереження й публікація літературної спадщини брата. За життя Ф. Сідні не надрукував жодного зі своїх творів, його поетичні тексти були відомі лише у вузькому колі друзів і рідних, а більшість поезій взагалі залишилася не закінченою. Тому Мері береться за важку справу - відредагувати, дописати й видати поетичний матеріал, який залишив брат. Вона редагує й завершує «Аркадію», доповнюючи текст своїми поетичними вставками, чим засвідчує власний талант, адже тексти Філіпа не повинні були б стати «гіршими», «зашкодити» репутації брата. Разом із другом дитинства Ф. Сідні та його першим біографом Ф. Гревіллем і кількома близькими особами Мері публікує 
«Захист поезії»; організовує видання збірки творів Філіпа, додаючи до неї й відредагований текст сонетів «Астрофіл і Стелла». Тоді ж було надруковано і «Траурну пісню Клорінди» - поему, яку написала Мері Герберт у знак скорботи за братом, де описова інтонація здебільшого витісняється безпосередньою емоційною, відкриває перед читачами глибокий сум за Філіпом. Поетеса говорить, що ліси, пагорби й ріки відтепер у руїнах, адже їх полишив той, хто дарував їм милість; поля плачуть як вдови; померли найпрекрасніші квіти, занепавши через його смерть. Мері називає брата Астрофілом, а його відхід у небуття вважає подією, про яку всі будуть шкодувати: Woods, hills and riuers, now are desolate / Sith he is gone the which them all did grace: / And all the fields do waile their widow state / Sith death their fairest flowre did late deface. / The fairest flowre in field that euer grew / Was Astrophel: that was, we all may rew (Herbert 1595 : 25-30).

У к. XVI ст. Мері Герберт починає вести активну перекладацьку діяльність. Публікуються іï переклади творів: «Роздуми про життя і смерті» Ф. Дюплессі-Морне, «Марк Антоній» Р. Гарньє, «Тріумф смерті» Петрарки. Значущим $\epsilon$ те, що в літературному матеріалі графині Пембрук простежуються іiі особисті почуття, відчувається любов і відданість братові, звучить невимовна туга й біль від втрати близької людини. Зокрема, перекладаючи «Тріумф смерті», Мері акцентує увагу читачів на тому, що є речі, які всі вважають дуже вартісними або незмінними. Проте насправді цінність «скіпетрів, корон, пурпурного кольору, коштовних митр, перлин і дорогоцінних каменів» - того, що символізує владу, є невисокою, навіть примарною, і коли настане смертний час (відбудеться зустріч із «Великою Матір'ю»), залишити своє ім'я в історії зможуть лише найталановитіші, один із яких - Філіп Сідні: Sceptres, and crowns, and robes, and purple die / And costly mitres, set with pearl and stone? / O wretch, who dost in mortal things affy! (Yet who but doth?). And if in end they find / Themselves beguil'd, they find but right, say I. / What means this toil? O blind, O more than blind / You all return to your great mother old / And hardly leave your very names behind (Herbert 1600:83-90). 
Пізніше Мері Герберт звертається до перекладу інших творів Петрарки. Попри те, що вже було декілька англомовних варіантів текстів італійського поета, уважається, що поетичний рівень, продемонстрований Мері, затьмарив навіть переклади, виконані самою королевою Слизаветою [Young 1912:208]. Mері Герберт зберегла струнку строфіку, принципи римування й метрики оригіналу, віднайшла унікальні поетичні можливості для відтворення емоційних особливостей віршів видатного італійця. Вишукану, піднесену картину почуттів, яку вона передає, високо поцінували читачі, не без підстави вважаючи іï тексти одними з найкращих.

Особливу увагу й інтерес дослідників викликають рукописні переклади біблійних псалмів, зроблені графинею Пембрук. Спочатку над перекладами працював Ф. Сідні, але за життя він устиг передати англійською мовою тексти лише 43 псалмів, інші 107 псалмів перекладала Мері. Засадничим можна уважати те, що у своїх текстах вона суворо не дотримується правил віршування оригіналу, відтворюючи лише його форму чи загальний зміст. Перекладачка не лише не дозволяє собі без переосмислення сприймати стародавні авторитети, але й доводить, що англійська мова самобутня, здатна бути цікавою для літературної праці. Ї̈̈ поетичні експерименти - це «натяки» на давні образи, вони сприймаються як авторські міркування на тему того чи того псалма. Мері послуговується багатьма можливими формами строфіки: дво-, три-, чотиривірші, по-різному їх компанує, експериментує 3 римуванням, намагаючись застосувати складні комбінації, випробовує свій талант у різних розмірах вірша. Збереглися й варіанти тих самих псалмів, вони «відповідають» різним періодам творчості поетеси, підтверджуючи: авторка ретельно й вимогливо працювала зі своїми текстами. Свідченням того, як удосконалювався авторський стиль графині Пембрук, є, наприклад, пізній переклад 46-го біблійного псалма: God in this Cittys Center bides / What can this citty shake / Who can this citty take / Where God a present ayd resides? / Where Nations raged against it came / And empires did the same / Ayr did with thunder sound / Earth failed their feet with melting ground (Herbert 1595a:46, 17-24). 
Як і більшість робіт Мері Герберт, псалми зберегли відлуння особистої трагедії авторки, іiі горя від втрати не просто брата, а видатної особистості. Через гіркі почуття вона пише подвійну посвяту до зібрання переказів псалмів: першу - королеві Єлизаветі I, другу - «Ангельському духу незрівнянного Філіпа Сідні». Мері називає брата «чистим духом», якому адресовані іiі поезї, його «благословенна рука» надихнула жінку на творчість, його «таємнича сила» дала змогу поєднати музу Мері з «небесною» музою брата, «як земна річ поєднується 3 небесною», а його «сяюче проміння» освячує й інших людей: To thee, pure sprite, to thee alone's addressed / This coupled work, by double int'rest thine: / First raised by thy blessed hand, and what is mine / Inspired by thee, thy secret power impressed. / So dared my Muse with thine itself combine / As mortal stuff with that which is divine. / Thy light'ning beams give luster to the rest (Herbert 1595b : 1-7). Мері завдячує духу померлого брата за те, що він керував iii рукою під час написання текстів, уважає свої переклади «працею двох авторів».

Результатом експериментів Мері Герберт стає збірка прекрасних поетичних перекладів біблійних псалмів, що демонструють нескінченні можливості недооціненої англійської мови, вражаючи читачів віртуозністю слова й новизною вірша поетеси. Сучасники Мері зустріли переклади захоплено, їх цитували, ними зачитувалися, їх колекціонували, що і зробило цей матеріал значущим явищем англійської літератури.

Перу графині Пембрук належать і збірка «Англійський Гелікон» (1600), і поетичний пасторальний діалог, опублікований у 1602 році у збірці «Поетична Рапсодія». Книги, які видавалися за участі Мері, мали високий поліграфічний рівень, тому науковцям є потреба звернути увагу й на особисті зв’язки, вплив графині Пембрук у сфері видавничої справи. Поетеса та іï особистий друкар У. Понсонбі оприлюднювали творче надбання не тільки самої Мері Герберт і їі брата Філіпа Сідні, але і твори інших англійських письменників, завдяки чому багато 3 них стали відомими і впізнаваними. Проте ходили чутки, що графиня 
Пембрук отримувала немалі прибутки від видання тих чи тих книг, що в той час було нетиповим явищем.

Існують історичні свідчення й того, що Шекспір був близький до дому Пембрук та уілтонського гуртка Мері. У листі, написаному в жовтні 1603 року своєму синові Уільяму, графиня Пембрук просить його запросити до маєтку короля Якова, щоб він переглянув шекспірівську комедію «Як вам це сподобається», i до того додає: «Шекспір тут, серед нас» [цит за: Schoenbaum 1978:167]. Одним із цікавих фактів життя Мері є роль іï самої і всього сімейства Герберт у появі Великого Фоліо. Саме графиня Пембрук стає ініціатором і редактором видання, значення якого для світової літератури важко переоцінити. Двадцять шекспірівських п’єс, серед яких «Антоній і Клеопатра», «Макбет», «Юлій Цезар», було надруковано вже через сім років після смерті автора. Збірник повинен був побачити світ у 1622 році, але робота над ним була призупинена через смерть у 1621 році Мері Сідні Герберт. Шекспірівське Фоліо було завершене лише в 1623 році, із присвятою синам Мері - Уільяму та Філіпу, які відшкодували чималі витрати на друк, із тим зберігши в пам’яті нащадків роль у його виданні славетної матері.

Як бачимо, літературна й суспільна діяльність графині Пембрук міцно закріпила за нею право називатися видатною меценаткою, поетесою i перекладачкою свого часу, з ім'ям якої пов’язаний важливий етап у розвитку англійської літератури. Складно сказати про Мері Герберт краще, ніж в епітафіï, написаній поетом Уільямом Брауном із Тевісток: Під ц̧им надгробком / Спочиває джерело всієї поезї, / Сестра Сідні, мати Пембрук. / О Смерть, перш ніж тобі зустрінеться інша, як вона, / Настільки ж сповнена добра, мудрості і знань, - / Тебе саму встигне вразити нескінченний Час.

Перспективи подальших досліджень убачаємо у грунтовному аналізі поетичного надбання Мері Сідні Герберт, виявленні особливостей мотивів, стилістичних та образних засобів їі поезій, текстів перекладів у контексті єлизаветинсько-якобінського періоду історії англійської літератури. 


\section{БІБЛІОГРАФІЯ}

Гилилов 2000 - Гилилов И. М. Игра об Уильяме Шекспире, или Тайна великого феникса / И. М. Гилилов. - М. : Межд. Отношения, 2000. - 536 с.

ІАЛ 1943 - История английской литературы : в 3 т. / [под ред. М. П. Алексеева, И. И. Анисимова, А. А. Елистратовой и др.]. - М.-Л. : АН СССР, 1943 - 1958. - Т. 1. - Ч. 2 : Литература эпохи Возрождения. - 1943.

ІВЛ 1985 - История всемирной литературы : в 8 т. / [Г. П. Бердников (гл. ред.), А. С. Бушмин, Ю. Б. Виппер (зам. гл. ред.) и др.]. - М. : Наука, 1983-1994. - T. 3. - 1985. - 816 c.

ИКСЗЕ 1999 - История культуры стран Западной Европы в эпоху Возрождения / [под ред. Л. М. Брагиной]. - М. : Высшая школа, 1999. - 479 с.

ІЗЛСВ 2007 - Історія зарубіжної літератури середніх віків та доби Відродження : [підручник] / Г. Й. Давиденко, В. Л. Акуленко. - К. : Центр учбової літератури, 2007. - 248 с.

Новомирова 2003 - Новомирова В. Кто придумал Шекспира? / В. Новомирова. - К. : Свет на востоке, 2003. - 288 с.

Торкут 2005 - Торкут Н. Антистретфордіанські гіпотези: pro et contra / Н. Торкут // Ренесансні студії. - Запоріжжя, 2005. - Вип. 10. - С.8-22.

Fisken 1985 - Fisken B. W. «Mary Sidney's Psalmes: Education and Wisdom» in Silent for the Word: Tudor Women as Patrons, Translators, and Writers of Religious Works / B. W. Fisken. - Kent : Kent State University Press, 1985.P. $166-183$.

Herbert 1595 - Herbert M. The Doleful Lay of Clorinda [Electronic resource] / M. Herbert. - Access mode: http://www.luminarium.org/renlit/dolefull.htm (У дужках зазначено номери рядків).

Herbert 1595a - Herbert M. The Psalms [Electronic resource] / M. Herbert. Access mode: http://www.luminarium.org/renlit/psalm46.htm (У дужках зазначено номер псалма та номери рядків). 
Herbert 1595b - Herbert M. The Psalms Preface [Electronic resource] / M. Herbertю - Access mode: http://www.wwnorton.com/college/english/nael/noa/ pdf/27636_16u35 Pembroke.1_4.tp.pdf (У дужках зазначено номери рядків).

Herbert 1600 - Herbert M. The Triumph of Death [Electronic resource] / M. Herbert. - Access mode: http://www.english.cam.ac.uk/ceres/sidneiana/triumph2. htm (У дужках зазначено номери рядків).

Hogrefe 1977 - Hogrefe P. Women of Action in Tudor England / P. Hogrefe. Ames : Iowa State University Press, 1977. - P. 105-135.

Schoenbaum 1978 - Schoenbaum S. William Shakespeare: A compact documentary life / S. Schoenbaum. - L. : Oxford, 1978. - P. 167.

Young 1912 - Young F. B. Mary Sidney, Countess of Pembroke / F. B. Young. - L. : David Nutt, 1912. - 237 p. 